\title{
NKG2D Ligand 2
}

National Cancer Institute

\section{Source}

National Cancer Institute. NKG2D Ligand 2. NCI Thesaurus. Code C105591.

NKG2D lig and 2 (246 aa, $\sim 27 \mathrm{kDa}$ ) is encoded by the human ULBP2 gene. This protein

plays a role in the production of both cytokines and chemokines by natural killer cells. 